Brazilian Journal

of Chemical

ISSN 0104-6632

Engineering

\title{
ASSESSMENT OF PROCESS VARIABLES ON THE USE OF MACAUBA PULP OIL AS FEEDSTOCK FOR THE CONTINUOUS PRODUCTION OF ETHYL ESTERS UNDER PRESSURIZED CONDITIONS
}

\author{
T. A. da S. Colonelli ${ }^{1}$, C. P. Trentini ${ }^{2}$, K. A. dos Santos ${ }^{1}$, J. V. de Oliveira ${ }^{3}$, \\ L. Cardozo-Filho ${ }^{4}$, E. A. da Silva ${ }^{1}$ and C. da Silva ${ }^{2, *}$ \\ ${ }^{1}$ Centro de Engenharias e Ciências Exatas, Universidade Estadual do Oeste do Paraná, \\ Faculdade Street 645, Jardim La Salle, 85903-000 Toledo, PR, Brazil. \\ ${ }^{2}$ Departamento de Tecnologia, Universidade Estadual de Maringá, \\ Av. Angelo Moreira da Fonseca 180, 87506-370 Umuarama, PR, Brazil. \\ *E-mail: camiladasilva.eq@gmail.com; Phone: +55 44 36219300. Fax: +55 4436219326. \\ ${ }^{3}$ Departmento de Engenharia Química e de Alimentos, Universidade Federal de Santa Catarina, \\ C.P. 476, 88040-900 Florianópolis, SC, Brazil. \\ ${ }^{4}$ Departmento de Engenharia Química, Universidade Estadual de Maringá, \\ Av. Colombo 5790, 87020-900 Maringa, PR, Brazil.
}

(Revised: April 26, 2016; Accepted: June 2, 2016)

\begin{abstract}
This study evaluated the potential of macauba pulp oil (MPO) as a feedstock for continuous ester production using ethanol under pressurized conditions. Experiments were performed in order to obtain data for the effect of process variables on ethyl ester (FAEE) and free fatty acid (FFA) conversion in a catalyst-free process. From the results, it appears that the MPO to ethanol mass ratio and the pressure were the variables with more favorable effect on the evaluated response variables. The addition of n-hexane caused an increase in the production of esters; however, this had a negative effect on FFA conversion. The addition of water was unfavorable for oil processing with high acidity. In this process, esterification and transesterification occur simultaneously, and the high FFA content in MPO provides high yields ( $85 \mathrm{wt} \%$ of esters; $93 \%$ FFA conversion) at low temperature, since the esterification reaction rate is higher than the transesterification. The decomposition of fatty acids was evaluated and levels $<5 \%$ were observed under the evaluated experimental conditions.
\end{abstract}

Keywords: Acrocomia aculeata, continuous, catalyst-free, ethanol.

\section{INTRODUCTION}

Currently, soybean is the main raw material for biodiesel production in Brazil, accounting for $\sim 70 \%$ of national production, followed by beef tallow and cottonseed oil (ANP, 2014). However, the country has a large territory and climatic diversity, which gives great potential for production of cheaper raw materials (Silva

\footnotetext{
* To whom correspondence should be addressed
} 
and Freitas, 2008). The highest percentage of biodiesel production costs is caused by the price of the feedstock used (Robles-Medina et al., 2009), so the search for raw materials with low cost has become a key point towards economic competitiveness of this biofuel (Michelin et al. 2015).

Thus, other sources have been studied and can be used to obtain this biofuel. Among these is the fruit of macauba (Acrocomia aculeata), which stands out for its high yield potential because it can produce 4500 to 6000 liters of oil per hectare year (Bergmann et al., 2013; César et al., 2015), greater than the oil yield per hectare year of annual crops such as soybeans (560 liters), sunflower (774 liters) and castor (810 liters) (Bergmann et al., 2013). Ilha et al. (2014) showed that the biodiesel obtained from Acrocomia aculeata has acceptable properties for use in diesel engines; however, due to the predominant composition of unsaturated fatty acids, it requires the use of an antioxidant additive. Macauba oil is obtained from the pulp and almond, wherein the pulp comprises $\sim 45 \%$ of the fruit (Ramos et al., 2008) and has between 18.7 to $29 \mathrm{wt} \%$ of oil (Coimbra and Jorge, 2012; Ciconini et al., 2013). The literature reports the high FFA content in macauba pulp oil (Doná et al., 2013; Aguieiras et al., 2014; Iha et al., 2014; Navarro-Díaz et al., 2014; César et al., 2015), between 10.5 to $65.4 \mathrm{wt} \%$, due to the presence of fatty acids in the fruit tissues of Acrocomia aculeate (César et al., 2015) and because the oil is obtained by pressing and filtration without refining steps. The processing of this crude oil for biodiesel production requires the use of methods tolerant to free fatty acids (César et al., 2015).

Ilha et al. (2014) obtained macauba biodiesel using a two-step reaction: esterification of FFA with sulfuric acid and transesterification with potassium hydroxide. The use of the homogeneous catalysts requires the use of subsequent washing steps for removal of the catalyst from the product and thus leads to the generation of a high volume of effluents (Vyas et al., 2010).

Aguieiras et al. (2014) proposed the application of enzymatic hydroesterification of macauba oil (10.5 wt $\%$ of FFA) with yields of $85 \%$ in esters; however, long reaction times were applied at each step: 6 hours for hydrolysis and 4 hours for esterification. The alcoholysis of macauba oil ( $88.9 \mathrm{mg} \mathrm{KOH} \mathrm{g-1} \mathrm{oil)} \mathrm{in} \mathrm{a} \mathrm{process} \mathrm{assisted} \mathrm{by} \mathrm{ultrasound}$ is presented in the work of Michelin et al. (2015) using the commercial enzyme Novozym 435 as catalyst. In that study, the authors reported an ester yield of $75 \%$ at 60 minutes using $20 \%$ enzyme (by weight of the substrates), and reusing the enzyme was shown to be attractive for only five cycles. The results of Aguieiras et al. (2014) and Michelin et al. (2015) demonstrate the limitations of the enzyme-catalyzed method related to long reaction times or the need for high enzyme concentrations to reach satisfactory yields, which increases the process cost due to the high cost of the enzyme (Silva and Oliveira, 2014).
Aiming to solve the drawbacks of processes using homogeneous catalysts and enzymes, non-catalytic reactions in pressurized medium using alcohols at sub- or supercritical conditions can be applied, as it allows for the simultaneous transesterification of triacylglycerides and esterification of free fatty acids, and hydrolysis of triacylglycerides when water is present in the reaction medium (Warabi et al., 2004, Kusdiana and Saka, 2004). The fact that the alcohol is present under pressurized conditions in the reaction medium leads to higher solubility of the substrate, increasing reaction rates and ester yields (Silva and Oliveira, 2014). The use of this technique for MPO processing was reported by Navarro-Díaz et al. (2014) using ethanol and methanol in supercritical conditions; however, the FFA conversion under different reaction conditions was not reported. This was also seen in the work by Doná et al. (2013) for obtaining macauba biodiesel from interesterification with methyl acetate in supercritical conditions. The esterification reaction rate is faster than transesterification, and higher conversion of FFA can be obtained in subcritical conditions, as reported in the works of Vieitez et al. (2012) and Abdala et al. (2014a). Thus, since the MPO has high FFA levels, evaluation of the experimental conditions to allow the use of alcohol in subcritical conditions in the process has become a focus of study, and was not evaluated in the work by Navarro-Díaz et al. (2014).

Another difference in this study is related to the addition of co-solvent in the process, which may decrease the operational parameters such as temperature, pressure and the amount of alcohol (Muppanemi et al., 2012; Tan et al., 2010) as a result of the increasing mutual solubility between the oil and the alcohol (Abdala et al., 2014b). The use of n-hexane as co-solvent is effective in noncatalytic reactions, as can be seen in previous studies by our research group on the synthesis of ethyl esters from Jatropha oil (Silva et al., 2014) and used frying oil (Abdala et al., 2014b).

Based on the above, this work aimed to report experimental data on the reaction of macauba pulp oil with ethanol under pressurized conditions. The Plackett Burman (PB-12) experimental design was applied to assess the effects of process variables on ester yield and FFA conversion, and select the variables with the greatest influence on the reaction in pressurized conditions. The reactions were conducted under different operating conditions that made possible the use of ethanol as a suband supercritical fluid.

\section{MATERIALS AND METHODS}

Macauba pulp oil (Cocal - Brasil), ethanol (JT Baker 99.8\%) and n-hexane (Vetec 98.5\%) were used for the reaction without further treatment. Table 1 shows the fatty acid composition of the oil determined by 
gas chromatography using the procedure described by Navarro-Díaz et al. (2014). The oil has a FFA content of $70.26 \pm 0.05 \mathrm{wt} \%$ and water content of $0.76 \pm 0.001 \mathrm{wt} \%$. For analysis of the reaction products, standard analytical methyl heptadecanoate (Sigma Aldrich, 99.9\%), heptane (FMaia, 95\%), ethanol (FMaia, 95\%), ethyl ether (Nuclear), phenolphthalein (Nuclear), sodium hydroxide (Anidrol) and boron trifluoride-methanol (Sigma Aldrich) were used.

Table 1. Fatty acid composition of MPO.

\begin{tabular}{cc}
\hline Fatty acid & Content (wt\%) \\
\hline Capric & $0.14 \pm 0.01$ \\
Lauric & $1.42 \pm 0.08$ \\
Myristic & $0.45 \pm 0.01$ \\
Palmitic & $13.54 \pm 0.14$ \\
Palmitoleic & $1.38 \pm 0.01$ \\
Stearic & $3.87 \pm 0.03$ \\
Oleic & $69.95 \pm 0.18$ \\
Linoleic & $7.82 \pm 0.12$ \\
Linolenic & $0.52 \pm 0.02$ \\
Eicosanoic & $0.26 \pm 0.01$ \\
\hline
\end{tabular}

The reactions were conducted in duplicate using a laboratory scale unit and the experimental procedure presented elsewhere (Doná et al., 2013). The specifications of the tubular reactor used are presented in detail in the work of Abdala et al. (2014b). The experimental procedure basically consists of pumping the reaction mixture to the reactor, preheated at the reaction temperature, until the time needed to fill the reactor and pressurization system.

After the steady-state condition was reached, i.e., after a reactor space-time had elapsed at least two times, samples were collected and stored for later analysis. A Plackett and Burman experimental design with 12 assays (PB-12) was employed to evaluate the effects of five variables, keeping the residence time fixed at $25 \mathrm{~min}$. This methodology of screening design aims to select variables with the greatest influence on a certain response variable of interest (Rodrigues and Iemma, 2005). Residence time was defined as the time the mixed reactants remained in the tubular reactor, which equals the void volume of the reactor divided by the volumetric flow rate. Table 2 presents the process variables (design factors) and ranges investigated for the experimental designs used in this work. The MPO to ethanol mass ratios considered in Table 2, 1:0.5, 1:1.25 and $1: 2$, represent approximately $1: 10,1: 15$ and $1: 20$ MPO to ethanol molar ratios, respectively. The software Statistica ${ }^{\circledR} 7.0$ (Statsoft Inc., USA) was used to assist the design and statistical analysis of the results, considering a significance level of $95 \%$.

Table 2. Factors and levels investigated in the experimental design employed in this work in the simultaneous transesterification and esterification of macauba pulp oil (residence time fixed at $25 \mathrm{~min}$ ).

\begin{tabular}{cccc}
\hline Variable & \multicolumn{1}{c}{ Level } & $\mathbf{1}$ \\
\cline { 2 - 4 } & $\mathbf{- 1}$ & $\mathbf{0}$ & 573 \\
Temperature (K), T & 523 & 548 & 20 \\
Pressure (MPa), P & 10 & 15 & $1: 2$ \\
Mass ratio (MPO: ethanol), MR & $1: 0.5$ & $1: 1.25$ & 10 \\
Water addition (wt\%), W & 0 & 5 & 20 \\
Cosolvent addition (wt\%), CS & 0 & 10 & \\
\hline
\end{tabular}

The procedure reported by Silva et al. (2010) was utilized for the analysis of ethyl esters and decomposition. The samples were injected, in triplicate, in the gas chromatograph (Agilent GC 7890), equipped with flame ionization detector and a capillary column (ZB-WAX, $30 \mathrm{~m}$ x $0.25 \mathrm{~mm} \times 0.1 \mu \mathrm{m})$. The quantification of the ester content in the samples followed the standard UNE-EN 14103 method (2003) and the FAEE yield was then calculated based on the content of ethyl esters in the analyzed sample. To calculate the degree of decomposition, the equation proposed by Vieitez et al. (2008) was used. The term "decomposition" of fatty acids referred to the decrease in their percentages (determined by gas chromatography) due to the formation of other compounds, such as oxygenated compounds (Lee et al., 2012) and hydrocarbons (Shin et al., 2011).

The FFA content was determined by the Ca $5 \mathrm{a}-40$ method (AOCS, 1998) and FFA conversion was calculated based on the content of free fatty acids in the oil and in samples of the reaction medium, as reported by Abdala et al. (2014a). 


\section{RESULTS AND DISCUSSION}

Table 3 presents the matrix of the Plackett and Burman design with 12 assays (PB-12), with coded values for the independent (factors) variables: temperature, pressure,
MPO to ethanol mass ratio, water and co-solvent addition, with the response in terms of FAEE yield and FFA conversion. The effects of the process variables on the simultaneous esterification and transesterification of MPO under pressurized conditions are presented in Table 4.

Table 3. Matrix of the PB-12 experimental design (coded values) with answers in terms of FAEE yield and FFA conversion (residence time fixed at $25 \mathrm{~min}$ ).

\begin{tabular}{|c|c|c|c|c|c|c|c|}
\hline \multirow[b]{2}{*}{ Run } & \multicolumn{5}{|c|}{ Variable/level } & \multicolumn{2}{|c|}{ Answers } \\
\hline & $\mathbf{T}^{\mathbf{a}}$ & $\mathbf{P}^{\mathbf{a}}$ & $\mathbf{M R}^{\mathrm{a}}$ & $\mathbf{W}^{\mathbf{a}}$ & $\mathrm{CS}^{\mathrm{a}}$ & $\begin{array}{c}\text { FAEE } \\
\text { yield } \\
(\%)\end{array}$ & $\begin{array}{c}\text { FFA } \\
\text { conversion } \\
(\%)\end{array}$ \\
\hline 1 & 1 & -1 & 1 & -1 & -1 & $72.37 \pm 0.31$ & $91.74 \pm 0.66$ \\
\hline 2 & 1 & 1 & -1 & 1 & -1 & $72.13 \pm 0.22$ & $92.97 \pm 0.57$ \\
\hline 3 & -1 & 1 & 1 & -1 & 1 & $85.38 \pm 0.19$ & $93.95 \pm 0.72$ \\
\hline 4 & 1 & -1 & 1 & 1 & -1 & $82.47 \pm 0.42$ & $86.71 \pm 0.35$ \\
\hline 5 & 1 & 1 & -1 & 1 & 1 & $77.77 \pm 0.37$ & $69.18 \pm 0.46$ \\
\hline 6 & 1 & 1 & 1 & -1 & 1 & $84.65 \pm 0.28$ & $90.28 \pm 0.57$ \\
\hline 7 & -1 & 1 & 1 & 1 & -1 & $85.20 \pm 0.33$ & $82.89 \pm 0.36$ \\
\hline 8 & -1 & -1 & 1 & 1 & 1 & $70.31 \pm 0.47$ & $84.49 \pm 0.29$ \\
\hline 9 & -1 & -1 & -1 & 1 & 1 & $76.94 \pm 0.54$ & $65.58 \pm 0.33$ \\
\hline 10 & 1 & -1 & -1 & -1 & 1 & $82.09 \pm 0.62$ & $81.00 \pm 0.41$ \\
\hline 11 & -1 & 1 & -1 & -1 & -1 & $73.02 \pm 0.34$ & $83.87 \pm 0.39$ \\
\hline 12 & -1 & -1 & -1 & -1 & -1 & $73.82 \pm 0.42$ & $84.25 \pm 0.44$ \\
\hline $13-15$ & 0 & 0 & 0 & 0 & 0 & $72.55 \pm 0.36 \mathrm{~b}$ & $87.70 \pm 0.49 \mathrm{~b}$ \\
\hline
\end{tabular}

${ }^{a}$ See Table 2; baverage of three experiments.

Table 4. Effect of independent variables on the simultaneous transesterification and esterification of macauba pulp oil.

\begin{tabular}{ccccc}
\hline & \multicolumn{2}{c}{ FAEE yield (\%) } & \multicolumn{2}{c}{ FFA conversion (\%) $^{\text {p-level }^{\mathbf{a}}}$} \\
\hline Variable & Effect & p-level $^{\mathbf{a}}$ & Effect & $<0.001$ \\
Mean/Intercept & 76.92 & $<0.001$ & 84.66 & 0.010 \\
Temperature & 1.13 & 0.033 & 2.80 & 0.007 \\
Pressure & 3.35 & 0.003 & 8.22 & 0.001 \\
MPO to ethanol mass ratio & 4.10 & 0.002 & -7.21 & 0.001 \\
Water addition & -1.08 & 0.036 & -6.32 & 0.002 \\
Cosolvent addition & 3.02 & 0.004 & & \\
\hline
\end{tabular}

${ }^{\text {a }}$ statistical significance $\mathrm{p}<0.05$.

\section{Effect of MPO to ethanol mass ratio}

It can be seen in Table 4 that the MPO:ethanol mass ratio was the variable with the greatest significance in terms of ester yield and FFA conversion. Ester production may be favored by reaction displacement to the formation of products by increasing the alcohol to oil ratio beyond the stoichiometric value. In addition, an increase in ratio of ethanol to oil provided increased contact area between the reagents (Kusdiana and Saka, 2001) and decreased the critical temperature of the reaction mixture (Yujaroen et al., 2009; Olivares-Carrillo et al., 2014).

Sammiang et al. (2014) reported the effect of the oil to ethanol molar ratio on the ester yield obtained from Krating oil (with an acid value of $29 \mathrm{mg} \mathrm{KOH} \mathrm{g-1);} \mathrm{using}$ ratios of $1: 20$ and $1: 40,76.5$ and $84.6 \mathrm{wt} \%$ esters was obtained, respectively, for reactions carried out at $533 \mathrm{~K}$, 5 minutes and $16 \mathrm{MPa}$. Similar results were observed in 
the work of Gonzalez et al. (2013), where the yield of the reaction between ethanol and waste frying oil increased from 49.9 to $64.7 \%$ at $1: 20$ and $1: 40$, respectively, for reactions conducted at $573 \mathrm{~K}$ and $20 \mathrm{MPa}$.

An increase in the methanol:oil mass ratio from 0.5:1 to $1: 1$ favors the conversion of oleic acid at $583 \mathrm{~K}$ and $25 \mathrm{MPa}$, as shown by Ding et al. (2011). The same effect was observed in a study by Jin et al. (2015) by varying the methanol:oleic acid molar ratio from 1:1 to $20: 1$ at $533 \mathrm{~K}$.

\section{Effect of Pressure}

From Table 4, it appears that an increase of pressure from 10 to $20 \mathrm{MPa}$ caused an increase in the production of esters; however, the effect on the ester yield was more pronounced, considering the yield of esterification and transesterification reactions, than the FFA conversion. The solubility of free fatty acids at sub- or supercritical fluid conditions is greater than that of triacylglycerols, so the esterification reaction can proceed more easily (Warabi et al., 2004). Increased pressure favors the solubility of ethanol in oil. Accordingly, at higher pressures, the ethanol and oil form a more homogeneous mixture, thus facilitating the reaction.

An increase in pressure from 15 to $20 \mathrm{MPa}$ favored obtaining esters of Jatropha oil at $573 \mathrm{~K}$, with oil:ethanol mass ratio of 1:1 and $28 \mathrm{~min}$, as shown by Silva et al. (2014). Under these conditions, the authors reported an increase in esters from 42 to $60 \mathrm{wt} \%$. In the transesterification of macauba oil, with high acidity, Navarro-Díaz et al. (2014) reported an increase in the yield of ethyl esters from 43.1 to $53.3 \mathrm{wt} \%$ after increasing the pressure from 10 to $20 \mathrm{MPa}$ at $573 \mathrm{~K}$ and 1:20 oil to ethanol molar ratio.

The work of Abdala et al. (2014a) reported that an increase in pressure from 15 to $20 \mathrm{MPa}$ favors the conversion of oleic acid in ethanol for reaction times of 20 to 30 min using 1:6 oleic acid to ethanol molar ratio and temperatures of 523 and $528 \mathrm{~K}$. Another study of interest is that of Wang et al. (2008), who investigated the effect of pressure on the reaction of soybean oil and a mixture of soybean oil+oleic or stearic acid with supercritical methanol and reported an increase in yield after increasing the pressure from 9 to $15 \mathrm{MPa}$.

\section{Effect of Temperature}

The alcoholysis reaction under pressurized conditions requires the application of high temperature conditions to obtain alcohol at sub- or supercritical conditions. In the reaction of MPO with ethanol, the temperature proved to be favorable in both reactions in the range of 523 to $573 \mathrm{~K}$, as seen in Table 4. A temperature increase at higher pressures led to better miscibility between the triacylglycerols and alcohol (Tang et al., 2006), obtaining the supercritical phase for the triolein-ethanol system above $543 \mathrm{~K}$ at 200 bar and triolein:ethanol molar ratio of 1:42 (Almagrbi et al., 2012).

From the results in Table 3, it can be seen that high ester yields ( $>85 \mathrm{wt} \%$ ) were obtained in the lower temperature reactions (runs 3 and 7). Esterification is a one-step reaction that can make it easier for the reaction to reach completion, whereas transesterification consists of three consecutive and reversible reactions. Thus, the effect of increasing the temperature under pressurized conditions is more pronounced for transesterification than for esterification, and it is possible to obtain high yields at low temperatures by increasing the FFA content in the oil.

In the transesterification of refined palm oil, Ngamprasertsith et al. (2014) showed an increase in the ethyl esters content from 45 to $72 \%$ upon increasing the temperature from 543 to $573 \mathrm{~K}$ at $20 \mathrm{MPa}$ and 1:30 oil:ethanol molar ratio. Another interesting study was presented by Farobie and Matsumura (2015) for ethyl transesterification of canola oil; these authors reported increased ester yield of 17 to $38 \mathrm{wt} \%$ when the reaction temperature increased from 543 to $573 \mathrm{~K}$ at $20 \mathrm{MPa}$, for 15 minutes and oil to ethanol molar ratio of 1:40.

In the case of esterification, a temperature increase from 523 to $563 \mathrm{~K}$ caused an increase in the oleic acid conversion from 80 to $\sim 93 \%$, as can be seen in the results published by Ding et al. (2011) for reactions conducted at 25 minutes, with oleic acid:methanol mass ratio of 1:1 and $25 \mathrm{MPa}$. Abdala et al. (2014a) reported high conversion of oleic acid, i.e. $70 \%$, in the reaction with ethanol at $20 \mathrm{MPa}$, with 1:1 oleic acid to ethanol mass ratio and 10 minutes at $473 \mathrm{~K}$; this conversion increased to $88 \%$ at $573 \mathrm{~K}$.

\section{Effect of Cosolvent Addition}

In an attempt to improve the reaction efficiency, n-hexane was added to the reaction mixture in proportions of 10 and $20 \mathrm{wt} \%$ (relative to oil). It was verified from the results (Table 4) that the transesterification reaction was favored, since the cosolvent increased the mutual solubility between ethanol and oil, thus reducing mass transfer limitations and increasing the reaction rates (Muppanemi et al., 2012; Silva et al., 2014). Using heptane as the cosolvent, Tan et al. (2010) reported a decrease in the optimum reaction temperature from 633 to $553 \mathrm{~K}$ with a cosolvent to methanol molar ratio of 0.15 .

The use of n-hexane had a favorable effect on the increased production of esters for different reaction systems (Patil et al., 2010; Muppanemi et al., 2012; Abdala et al., 2014b; Silva et al., 2014). In this regard, we can cite the work developed by Patil et al. (2010), which evaluated the addition of n-hexane in the methyl transesterification of camelina oil at $563 \mathrm{~K}$, with 1:25 oil:methanol molar ratio, $114 \mathrm{bar}$ and $40 \mathrm{~min}$ of reaction. The ester yield increased from $46.6 \%$ to $88 \%$ with the addition of $20 \%$ (by volume of oil) of the cosolvent. Muppanemi et al (2012) report 
that, with the addition of $10 \%$ cosolvent (by volume of oil), the yield of esters increases from 45 to $70 \%$ at 568 $\mathrm{K}, 1: 25$ oil to methanol molar ratio, 110 bar and $20 \mathrm{~min}$ of reaction. The addition of a cosolvent was also effective in the transesterification of used frying oil as the ester yield increased from $34 \mathrm{wt} \%$ without a cosolvent, to 72 wt $\%$ with the addition of $20 \mathrm{wt} \%$ of $\mathrm{n}$-hexane, at $573 \mathrm{~K}$, oil:ethanol mass ratio of 1:1, $20 \mathrm{MPa}$ and $40 \mathrm{~min}$ (Abdala et al., 2014b).

Regarding the esterification, the addition of a solvent has a negative effect on FFA conversion. Imahara et al. (2009) reports that the addition of n-hexane can dilute the reactants, thus decreasing the reaction rate. The authors also mention that this effect is more pronounced at elevated temperatures, explaining the low FFA conversion obtained at $573 \mathrm{~K}$ with $20 \%$ of cosolvent (runs 5 and 9 ).

Whereas the transesterification reaction has lower reaction rates and required higher temperature conditions to provide high yields of esters, when compared to esterification, the overall assessment of the cosolvent effect is that it is favorable for obtaining esters of macauba pulp oil, with high acidity, using pressurized ethanol.

\section{Effect of Water Addition}

Water addition to the reaction medium was found to be unfavorable for the production of esters from MPO under our experimental condition. The presence of water causes the production of FFA by the hydrolysis of triacylglycerols (Kusdiana and Saka, 2004) and can also cause hydrolysis of the esters formed during the reaction (Yujaroen et al., 2009; Ding et al., 2011; Go et al., 2014).

The work of Navarro-Díaz et al. (2014), relating to the reaction of macauba oil with high acidity, i.e. $56.3 \mathrm{wt} \%$
FFA, shows that the addition of water to a level of $10 \mathrm{wt} \%$ (to ethanol) at $573 \mathrm{~K}, 20 \mathrm{MPa}$ and oil:ethanol molar ratio of 1:40 reduced the yield of ethyl esters, compared to the reaction without water, for all residence times considered under these conditions. Similar observations were reported by Yujaroen et al. (2009) upon the addition of 5 to $30 \%$ $(\mathrm{v} / \mathrm{v})$ in the esterification of a palm fatty acid distillate using supercritical methanol. The authors also evaluated the hydrolysis of esters at different reaction times and found than $573 \mathrm{~K}$ and $25 \mathrm{~min}$ led to the hydrolysis of $\sim 20 \%$ of methyl esters.

\section{Comparison with the literature}

Based on the effects observed for each variable, the highest ester yield $(85.38 \mathrm{wt} \%)$ was obtained at $523 \mathrm{~K}, 20$ $\mathrm{MPa}$, and MPO:ethanol mass ratio of 1:2, without water and $20 \mathrm{wt} \%$ of the cosolvent. The high FFA content of MPO provides a high yield of esters in ethanol subcritical conditions due to the high conversion of FFA, i.e. $93.95 \%$, under these conditions. This result is greater than the highest yield, $69.6 \%$, reported by Navarro-Diaz et al. (2014) at $598 \mathrm{~K}, 15 \mathrm{MPa}$, oil:ethanol molar ratio of 1:30, 5 $\mathrm{wt} \%$ water added to the ethanol and 35 minutes of reaction, obtained at low temperature.

Table 5 shows a comparison of the results obtained in this work with recent data published in the literature for reactions using ethanol under pressurized conditions. From the data in this table, it appears that the high amount of FFA in macauba oil might act as a catalyst to accelerate the reaction to produce more esters. This fact, coupled with the use of co-solvent in the process, provided high ester yields at low reaction temperature and short reaction time when compared to other studies.

Table 5. Comparison of the results obtained in this work with the literature using ethanol in pressurized conditions.

\begin{tabular}{|c|c|c|c|}
\hline Oil; acidity & Conditions & FAEE $(\mathbf{w t} \%)$ & Reference \\
\hline Macauba pulp oil; $70.25 \mathrm{wt} \%$ of FFA & $\begin{array}{l}1: 2 \text { oil to ethanol mass ratio ( } \sim: 20 \text { oil to ethanol molar } \\
\text { ratio); } 523 \mathrm{~K} ; 20 \mathrm{MPa} ; 25 \text { minutes and } 20 \mathrm{w} \% \text { of } \\
\text { cosolvent addition }\end{array}$ & 85.38 & This Work \\
\hline Waste fried oil; $1.5 \mathrm{wt} \%$ of FFA & $\begin{array}{l}\text { 1:30 oil to ethanol molar ratio; } 598 \mathrm{~K} ; 15 \mathrm{MPa} \text {; } \\
\sim 46 \text { minutes and } 5 \mathrm{w} \% \text { of water addition }\end{array}$ & 82.2 & $\begin{array}{l}\text { Gonzalez et al. } \\
\qquad(2013)\end{array}$ \\
\hline Waste fried oil; 3.73 mg KOH.g-1 & $\begin{array}{l}1: 20 \text { oil to ethanol molar ratio; } 573 \mathrm{~K} ; 20 \mathrm{MPa} \text {; } \\
70 \text { minutes and } 20 \mathrm{w} \% \text { of cosolvent addition }\end{array}$ & $\sim 87$ & $\begin{array}{l}\text { Abdala et al. } \\
\qquad(2014 \mathrm{~b})\end{array}$ \\
\hline Used palm olein oil; 11.1 mg KOH.g-1 & $\begin{array}{l}\text { 1:30 oil to ethanol molar ratio; } 573 \mathrm{~K} ; 30 \mathrm{MPa} \text {; } \\
\sim 40 \text { minutes }\end{array}$ & 70 & $\begin{array}{l}\text { Ngamprasertsith et al. } \\
\text { (2014) }\end{array}$ \\
\hline Macauba pulp oil; 56.3 wt $\%$ of FFA & $\begin{array}{l}1: 30 \text { oil to ethanol molar ratio, } 598 \mathrm{~K}, 15 \mathrm{MPa} \text {, } \\
35 \text { minutes and } 5 \mathrm{wt} \% \text { of water addition }\end{array}$ & 69.6 & $\begin{array}{l}\text { Navarro-Diaz et al. } \\
\qquad(2014)\end{array}$ \\
\hline Jatropha oil; $10.1 \mathrm{wt} \%$ of FFA & $\begin{array}{l}1: 20 \text { oil to ethanol molar ratio; } 573 \mathrm{~K} ; 20 \mathrm{MPa} \text {; } \\
52 \text { minutes }\end{array}$ & 80 & $\begin{array}{l}\text { Silva et al. } \\
\text { (2014) }\end{array}$ \\
\hline Camelina oil; $1.7 \mathrm{wt} \%$ of FFA & $\begin{array}{l}\text { 1:40 oil to ethanol molar ratio; } 583 \mathrm{~K} ; 20 \mathrm{MPa} \text {; } \\
30 \text { minutes }\end{array}$ & 86 & $\begin{array}{l}\text { Sun et al. } \\
(2014)\end{array}$ \\
\hline Canola oil; not reported & $\begin{array}{l}\text { 1:40 oil to ethanol molar ratio; } 573 \mathrm{~K} ; 3.54 \mathrm{MPa} \text {; } \\
25 \text { minutes }\end{array}$ & $\sim 60$ & $\begin{array}{l}\text { Farobie and Matsumura } \\
\qquad(2015)\end{array}$ \\
\hline
\end{tabular}




\section{Decomposition of Fatty Acids}

Figure 1 illustrates the decomposition of fatty acids for the experimental runs shown in Table 3. It can be seen from the results in Figure 1 that up to 5\% decomposition was observed under all evaluated conditions. The highest levels of decomposition were observed for reactions conducted at $573 \mathrm{~K}$ (runs 5 and 6), followed by the midpoint of the conditions at $548 \mathrm{~K}$ (runs 13 to 15 ). For experiments conducted at $523 \mathrm{~K}$ (runs $8,9,11$ and 12), low values $(<0.2 \%)$ for decomposition of fatty acids were observed. Analysis of these data shows the high influence of temperature on the decomposition of fatty acids, as already reported by Silva et al. (2010), Vieitez et al. (2012) and Silva et al. (2014). The best ester yield was observed at a temperature of $523 \mathrm{~K}$ (run 3 ) and in this condition $\sim 1 \%$ decomposition was reported, consistent with the results of Vieitez et al. (2010), who reported on the high stability of ethyl esters at this temperature.

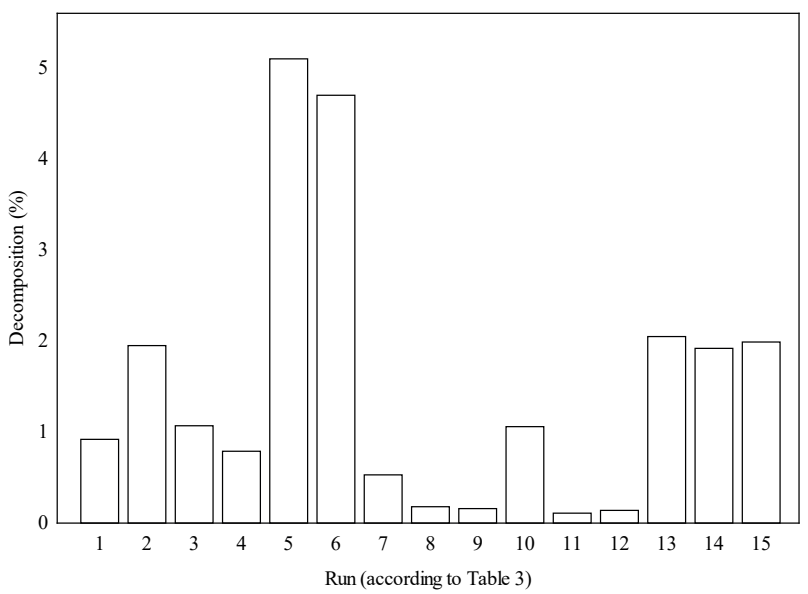

Figure 1. Decomposition of fatty acid from the conditions of Table 3.

For the studied system (macauba pulp oil/ethanol) and evaluated experimental range a direct correlation between decomposition and the variables considered in Table 2 was not observed, probably because of the low decomposition levels observed. These low levels of decomposition may be related to the high content of free fatty acids in the oil, since Vieitez et al. (2012) reported that increasing the acidity of the oil reduced decomposition. The authors reported that this effect may have been due to the lower availability of glycerol in the reaction medium, which decreases the occurrence of side reactions between this byproduct and other components of the reaction medium.

\section{CONCLUSIONS}

In this work, the continuous and non-catalytic reaction of macauba pulp oil (MPO) with ethanol under pressurized conditions was studied to assess the operational variables in the use of this feedstock for biodiesel production. The variable MPO:ethanol mass ratio had the greatest influence on the evaluated reaction parameters, followed by pressure and temperature. The production of esters was favored by the addition of n-hexane in the reaction medium. The possible hydrolysis of esters upon the addition of water was unfavorable in this system. The reaction of MPO with high acidity using a cosolvent in the reaction mixture can be conducted at low temperatures in high yields ( 85 wt $\%$ of esters, $93 \%$ conversion of FFA) and low levels of decomposition $(\sim 1 \%)$.

\section{ACKNOWLEDGEMENT}

The authors thank CNPq and Fundação Araucária for the financial support and West Paraná State University (UNIOESTE) for the scholarship.

\section{REFERENCES}

Abdala, A.C.A., Garcia, V.A.S., Trentini, C. P., Cardozo-Filho, L., Silva, E.A., Silva, C. Continuous Catalyst-Free Esterification of Oleic Acid in Compressed Ethanol. International Journal of Chemical Engineering 1, 1-5 (2014a).

Abdala, A.C.A., Colonelli, T.A.S., Trentini, C. P., Oliveira, J. V., Cardozo-Filho, L., Silva, E.A., Silva, C. Effect of Additives in the Reaction Medium on the Noncatalytic Esters from Used Frying Oil with Supercritical Ethanol. Energy \& Fuels 28, 3122-3128 (2014b).

Aguieiras, E.C.G., Cavalcanti-Oliveira, E.D., Castro, A.M., Langone, M.A.P., Freire, D.M.G. Biodiesel production from Acrocomia aculeata acid oil by (enzyme/enzyme) hydroesterification process: Use of vegetable lipase and fermented solid as low-cost biocatalysts. Fuel 135, 315-321 (2014).

Almagrbi, A.M., Glisic, S.B., Orlovic, A.M. The phase equilibrium of triglycerides and ethanol at high pressure and temperature: The influence on kinetics of ethanolysis. Journal of Supercritical Fluids 61, 2-8 (2012).

ANP - Agência Nacional do Petróleo, Gás Natural e Biocombustíveis, ANP. Brasília, Brasil, January (2014). Retrieved from http://www.anp.gov.br.

Bergmann, J.C., Tupinambá, D.D., Costa, O.Y.A., Almeida, J.R.M., Barreto, C.C., Quirino, B.F. Biodiesel production in Brazil and alternative biomass feedstocks. Renewable \& Sustainable Energy Reviews 21, 411-420 (2013).

César, A.S., Almeida, F.A., Souza, R.P., Silva, G.C., Atabani, A.E. The prospects of using Acrocomia aculeata (macaúba) a non-edible biodiesel feedstock in Brazil. Renewable \& Sustainable Energy Reviews 49, 1213-1220 (2015).

Ciconini, G., Favaro, S.P., Roscoe, R., Miranda, C.H.B., Tapeti, C.F., Miyahira, M.A.M., Bearari, L., Galvani, F., Borsato, A.V., Colnago, L.A., Naka, M.H. Biometry and oil contents of Acrocomia aculeata fruits from the Cerrados and Pantanal biomes in Mato Grosso do Sul, Brazil. Industrial Crops and Products 45, 208- 214 (2013) 
Coimbra, M.C., Jorge, N. Fatty acids and bioactive compounds of the pulps and kernels of Brazilian palm species, guariroba (Syagrus oleraces), jerivá (Syagrus romanzoffiana) and macaúba (Acrocomia aculeata). Journal of the Science of Food and Agriculture 92, 679-684 (2012).

Ding, J., He, B., Li, J. Biodiesel production from acidified oils via supercritical methanol. Energies 4, 2212-2223 (2011).

Doná, G., Cardozo Filho, L., Silva, C., de Castilhos, F. Biodiesel production using supercritical methyl acetate in a tubular packed bed reactor. Fuel Processing Technology 106, 605610 (2013).

Farobie, O., Matsumura, Y. A comparative study of biodiesel production using methanol, ethanol, and tert-butyl methyl esther (MTBE) under supercritical methanol. Bioresource Technology 191, 306-311 (2015).

Go, A.W., Nguyen, P.L.T., Huynh, L.H., Liu, Y.T., Sutanto, S., Ju, Y.H. Catalyst free esterification of fatty acids with methanol under subcritical condition. Energy 70, 393-400 (2014).

Gonzalez, S.L., Sychoski, M.M., Navarro-Díaz, H.J., Vieitez, I., Jachmanián, I., Silva, C., Hense, H., Oliviera, J. V. Continuous catalyst-free production of biodiesel through transesterification of soybean fried oil in supercritical methanol and ethanol. Energy \& Fuels 27, 5253-5259 (2013).

Ilha, O.K., Alves, F.C.S.C., Suarez, P.A.Z., Oliveira, M.B.F., Meneghetti, S.M.P., Santos, B.P.T., Soletti, J.I. Physicochemical properties of Syagrus coronata and Acrocomia aculeata oils for biofuel production. Industrial Crops and Products 62, 318- 322 (2014).

Imahara, H., Xin, J.Z., Saka, S. Effect of CO2/N2 addition to supercritical methanol on reactivities and fuel qualities in biodiesel production. Fuel 88, 1329-1332 (2009).

Jin, T., Wang, B., Zeng, J., Yang, C., Wang, Y., Fang, T. Esterification of free fatty acids with supercritical methanol for biodiesel production and related kinetic study. RSC Advances 5, 52072-52078 (2015).

Kusdiana, D., Saka, S. Biodiesel fuel from rapeseed oil as prepared in supercritical methanol. Fuel 80, 225-231 (2001).

Kusdiana, D., Saka, S. Effects of water on biodiesel fuel production by supercritical methanol treatment. Bioresource Technology 91, 289-295 (2004).

Lee, S., Posarac, D., Ellis, N. An experimental investigation of biodiesel synthesis from waste canola oil using supercritical methanol. Fuel, 91, 229-237 (2012).

Michelin, S., Penha, F.M., Sychosky, M.M., Schere, R.P., Treichel, H., Valério, A., Di Luccio, M., Oliveira, D., Oliveira, J.V. Kinetics of ultrasound-assisted enzymatic biodiesel production from Macauba coconut oil. Renewable Energy 76, 388-393 (2015).

Muppaneni, T., Reddy, H.K., Patil, P.D., Dailey, P., Aday, C., Deng, S. Ethanolysis of camelina oil under supercritical condition with hexane as a co-solvent. Applied Energy 94, 84-88 (2012).

Navarro-Díaz, H.J., Gonzalez, S.L., Irigaray, B., Vieitez, I., Jachmanián, I., Hense, H., Oliveira, J.V. Macauba oil as an alternative feedstock for biodiesel: Characterization and ester conversion by the supercritical method. Journal of Supercritical Fluids 93, 130-137 (2014).
Ngamprasertsith, S., Laetoheem, C., Sawangkeaw, R. Continuos production of biodiesel in supercritical ethanol: A comparative study between refined and used palm olein oils as feedstocks. Journal of the Brazilian Chemical Society 25, 1746-1753 (2014).

Olivares-Carrillo, P., Quesada-Medina, J., Ríos, A.P., HernándezFernández, F.J. Estimation of critical properties of reaction mixtures obtained in different reaction conditions during the synthesis of biodiesel with supercritical methanol from soybean oil. Chemical Engineering Journal 241, 418-432 (2014).

Patil, P.D., Gude, V.G., Deng, S. Transesterification of Camelina Sativa oil using supercritical and subcritical methanol with cosolvents. Energy \& Fuels 24, 746-751 (2010).

Robles-Medina, A., González-Moreno, P.A., Esteban-Cerdán, L., Molina-Grima, E. Biocatalysis: Towards ever greener biodiesel production. Biotechnology Advances 27, 398-408 (2009).

Rodrigues, M.I., Iemma, A.F. Planejamento de experimentos e otimização de processos: Uma estratégia sequencial de planejamentos. Casa do Pão Editora, Campinas - SP, 2005.

Rodríguez-Guerrero, J.K., Rubens, M.F., Rosa, P.T.V. Production of biodiesel from castor oil using sub and supercritical etanol: Effect of sodium hydroxyde in the ethyl ester production. Journal of Supercritical Fluids 83, 124-132 (2013).

Samniang, A.S., Tipachan, C., Kajorncheappun-ngan, S. Comparion of biodiesel production from crude Jatropha oil and Krating oil by supercritical metanol transesterification. Renewable Energy 68, 351-355 (2014).

Silva, P.R.F., Freitas, T.F.S. Biodiesel: o ônus e o bônus de produzir combustível. Ciência Rural. 38, 843-851 (2008).

Silva, C., Castilhos F., Oliveira, J.V., Cardozo Filho, L. Continuous production of soybean biodiesel with compressed ethanol in a microtube reactor. Fuel Processing Technology, 91, 1274-1281 (2010).

Silva, C., Colonelli, T.A.S., Silva, E. A., Cabral, V.F., Oliveira, J. V., Cardozo-Filho, L. Continuous catalyst-free production of esters from Jatropha curcas L. oil under supercritical ethanol. Brazilian Journal of Chemical Engineering 31, 727-735 (2014).

Silva, C., Oliveira, J.V. Biodiesel production through noncatalytic supercritical transesterification: current state and perspectives. Brazilian Journal of Chemical Engineering 31, 271-285 (2014).

Shin, H., Lim, S., Bae, S., Oh, C. Thermal decomposition and stability of fatty acid methyl esters in supercritical methanol. Journal of Analytical and Applied Pyrolysis, 92, 332-338 (2011).

Standard UNE-EN 14103. Determination of ester and linolenic acid methyl ester contents, issued by Asociación Española de Normalización y Certificación, Madrid (2003).

Sun, Y., Reddy, H.K., Muppaneni, T., Ponnusamy, S., Patil, P.D., Li, C., Jiang, L., Deng, S. Fuel 135, 530-536 (2014).

Tan, T.K., Lee, K.T., Mohamed, A.R. Effects of free fatty acids, water content and co-solvent on biodiesel production by supercritical methanol reaction. Journal of Supercritical Fluids 53, 88-91 (2010). 
Tang, Z., Du, Z., Min, E., Gao, L., Jiang, T., Han, B. Phase equilibria of methanol-triolein system at elevated temperature and pressure. Fluid Phase Equilibria 239, 8-11 (2006).

Vieitez, I., Silva, C., Borges, G., Alkimim, I.P., Corazza, F.C., Oliveira, J. V., Grompone, M., Jachmanián, I. Effect of Temperature on the Continuous Synthesis of Soybean Esters under Supercritical Ethanol. Energy \& Fuels 23, 558-563 (2008).

Vieitez, I., Silva, C., Alkimim, I.P., Castilhos, F., Oliveira, J. V., Grompone, M., Jachmanián, I. Stability of ethyl esters from soybean oil exposed to high temperatures in supercritical ethanol. Journal of Supercritical Fluids 56, 265-270 (2010).

Vieitez, I., Irigaray, B., Casullo, P., Pardo, M.J., Grompone, M., Jachmanián, I. Effect of free fatty acids on the efficiency of the supercritical ethanolysis of vegetable oils from different origins. Energy \& Fuels 26, 1946-1951 (2012).
Vyas, A.P., Verma, J.L., Subrahmanyam, N. A review on FAME production processes. Energy \& Fuels 89, 1-9 (2010).

Wang, C.W., Zhou, J.F., Chen, W., Wang, W.G., Wu, Y.X., Zhang, J.F., Chi, R.A., Ying, W.Y. Effect of weak acids as a catalyst on the transesterification of soybean oil in supercritical methanol. Energy \& Fuels 22, 3479-3483 (2008).

Walker, R.E. Official Methods and Recommended Practices of the American Oil Chemists' Society (Method AOCS Ce 2-66), 4th Ed., American Oil Chemists' Society, Champaign (1990).

Warabi, Y., Kusdiana, D., Saka, S. Reactivity of triglycerides and fatty acids of rapeseed oil in supercritical alcohols. Bioresource Technology 91, 283-287 (2004).

Yujaroen, D., Goto, M., Sasaki, M., Shotpruk, A. Esterification of palm acid distillate (PFAD) in supercritical methanol: Effect of hydrolysis on reaction reactivity. Fuel 88, 2011-2016 (2011). 